University of Nebraska - Lincoln

DigitalCommons@University of Nebraska - Lincoln

Faculty Publications: Department of Teaching, Department of Teaching, Learning and Teacher Learning and Teacher Education

Education

2014

\title{
A Study on the Elementary School Teachers' Awareness of Students' Alternative Conceptions about Change of States and Dissolution
}

\author{
Chanho Yang \\ Seoul National University \\ Taehee Noh \\ Seoul National University \\ Lawrence C. Scharmann \\ University of Nebraska-Lincoln, Ischarmann2@unl.edu \\ Sukjin Kang \\ Jeonju National University of Education, kangsj@jnue.kr
}

Follow this and additional works at: https://digitalcommons.unl.edu/teachlearnfacpub

Part of the Chemistry Commons, Curriculum and Instruction Commons, and the Teacher Education and Professional Development Commons

Yang, Chanho; Noh, Taehee; Scharmann, Lawrence C.; and Kang, Sukjin, "A Study on the Elementary School Teachers' Awareness of Students' Alternative Conceptions about Change of States and Dissolution" (2014). Faculty Publications: Department of Teaching, Learning and Teacher Education. 383.

https://digitalcommons.unl.edu/teachlearnfacpub/383

This Article is brought to you for free and open access by the Department of Teaching, Learning and Teacher Education at DigitalCommons@University of Nebraska - Lincoln. It has been accepted for inclusion in Faculty Publications: Department of Teaching, Learning and Teacher Education by an authorized administrator of DigitalCommons@University of Nebraska - Lincoln. 


\title{
A Study on the Elementary School Teachers' Awareness of Students' Alternative Conceptions about Change of States and Dissolution
}

\author{
Chanho Yang, ${ }^{1}$ Taehee Noh, ${ }^{1}$ \\ Lawrence C. Scharmann, ${ }^{2}$ and Sukjin Kang ${ }^{3}$
}

\footnotetext{
1 Department of Chemistry Education, Seoul National University, Seoul, Korea

2 School of Teacher Education, Florida State University, Tallahassee, FL, USA; current affiliation-University of Nebraska-Lincoln

3 Department of Science Education, Jeonju National University of Education, Seohak-ro 50, Wansan-gu, Jeonju 560-757, Korea.

Corresponding author - email kangsj@jnue.kr
}

\begin{abstract}
Knowledge about students' conceptions is one of the requisite components of pedagogical content knowledge. A keen awareness of students' alternative conceptions provides teachers with information about prospective difficulties students may incur as they make attempts to learn more accurate scientific representations of critical concepts. In this study, we investigated elementary school teachers' understanding of their students' alternative conceptions about change of states and dissolution. The subjects were 152 elementary school teachers and 529 sixth graders in Korea. A conceptions test and the test of the understanding about students' conceptions were administered in order to examine students' alternative conceptions and the teachers' awareness of their students' alternative conceptions, respectively. The effects of teachers' characteristics such as teaching experience, highest academic degree, science teaching efficacy, and views about teaching and learning (i.e., constructivist
\end{abstract}

Published in The Asia-Pacific Education Researcher 23:3 (2014), 683-698

DOI 10.1007/s40299-013-0140

Copyright (C) 2013 De La Salle University; published by Springer. Used by permission.

Published 26 October 2013. 
and traditional) in relation to their awareness of students' alternative conceptions were also investigated. The results indicated that the teachers tended to overestimate the number of students with scientifically accepted conceptions. The teachers also did not possess adequate knowledge about the existence and the distribution of their students' alternative conceptions. It was found that teaching experience, highest academic degree, science teaching efficacy, and the level of teachers' adoption of a constructivist view about teaching and learning were not significantly related to the their awareness of students' alternative conceptions. It was found, however, that there is a significant relationship between the level of teachers' traditional view about teaching and learning and their awareness of students' alternative conceptions. Educational implications are discussed.

Keywords: Alternative conception, Pedagogical content knowledge, Elementary school teacher, View about teaching and learning

\section{Introduction}

The quality of one's educational system is directly related the quality of the teachers to whom we entrust the curriculum. Many researchers have contended that teachers, among other factors, play a central role in any model of educational improvement (Diakidoy and Iordanou 2003; NCEE 2006; OECD 2005) because teachers' knowledge and beliefs have a significant influence on students' holistic learning experiences. Effective teachers possess professional knowledge concerning how to plan and enact individual lessons to help students develop appropriate understanding (Fishman et al. 2003). What is as important, however, is for teachers to apply knowledge and skills beyond individual lessons, thus exhibiting a unique framework of their professional understanding (Barnett and Hudson 2001). With this growing awareness, research on teaching has focused attention on teachers' knowledge that may underlie effective teaching behaviors (Borko and Putnam 1996; Lederman and Niess 2001). As a result, pedagogical content knowledge (PCK) has been identified as a knowledge base that teachers should possess. PCK, in fact, has become an organizing precept in redesigning teacher education programs (AAAS 1993; Gimmestad and Hall 1995; NRC 1996).

PCK is recognized as a distinctive knowledge base to be distinguished from subject matter knowledge and/or pedagogical knowledge (Magnusson et al. 1999). The development of PCK involves a shift in teachers' knowledge from being able to understand subject matter content to becoming able to transform subject matter content 
in appropriate ways which are understandable to students (Grossman 1990; Hashweh 2005). Numerous attempts to conceptualize PCK, from the definitions of PCK to the components comprising it, have been delineated in previous studies (Appleton 2003; Gess-Newsome and Lederman 1999; Loughran et al. 2004; Zeidler 2002). Although there is no universally accepted conceptualization of PCK, most scholars agree that a knowledge of students' learning difficulties, conceptions, and alternative conceptions, is one of the requisite components of PCK (van Driel et al. 1998).

One of the reasons why students encounter difficulties in learning science is that their alternative conceptions are not consistent with scientifically accepted concepts. Many alternative conceptions, if not all, have been reported to be formed prior to formal instruction in science classes (Akerson et al. 2000; Barnett 2002; Pine et al. 2001). Alternative conceptions are often both pervasive and resistant to change through traditional expository forms of instruction (Eryilmaz 2002; Kang et al. 2004; Southerland et al. 2001). Alternative conceptions tend to be favored over scientific concepts because they emanate from students' everyday experiences and thus they might be, at least to some extent, intelligible, plausible, and useful for students to make sense of the world around them (Chi 2005; Crespo and Pozo 2004). In addition, alternative conceptions are part of a larger knowledge system that involves many interrelated conceptions which students use to make sense of their experiences.

Students' alternative conceptions tend to be sufficiently inaccurate or erroneous that they often hinder students' learning scientific concepts. The effective implementation of instructional strategies that address students' alternative conceptions is not as simple as following the steps in a recipe. Without sufficient knowledge of students' alternative conceptions, teachers cannot effectively create learning experiences through which students reorganize their knowledge (Akerson et al. 2000; Diakidoy and Iordanou 2003; Gomez-Zwiep 2008; Meyer 2004; Otero and Nathan 2008; Pine et al. 2001; Pringle 2006). Teachers lacking awareness of students' alternative conceptions may, in fact, unknowingly reinforce new alternative conceptions to their students during science instruction (Sanders 1993). For example, teachers who are better informed about students' alternative conceptions more effectively identify and elicit them and help their students make them explicit during science instruction (Linn and Muillenburg 1996; Pine et 
al. 2001). In addition, teachers with an appropriate knowledge of students' alternative conceptions are more likely to choose and to present effective learning experiences such as discrepant events, which are often the starting point of students' potential for conceptual change.

If we place students' prior knowledge as the central feature of constructivist learning, teachers have to be able to ascertain their students' alternative conceptions. Previous research has scrutinized students' alternative conceptions to provide teachers with the knowledge of those that are likely to be held by students of different ages in different subject areas. However, there is a gap between what research has revealed about students' alternative conceptions and how knowledge of this research gets transformed into practice in actual class settings (Duit et al. 2008; Gomez-Zwiep 2008). As Diakidoy and Iordanou (2003) reported, teachers tend to overestimate their students' knowledge about the topics they teach. In addition, teachers are neither informed about students' possible alternative conceptions that may influence subsequent instruction nor advised on how to respond to them. For example, Berg and Brouwer (1991) reported that physics teachers were generally unable to predict the different types and/or the proportions of students' alternative conceptions. In a second example, given a study on the elementary teachers' knowledge of students' conceptions of light and shadows, Smith and Neale (1991) also reported that teachers were oblivious to the presence of students' alternative conceptions. Nonetheless, there is still a lack of studies that explores how teachers aware their students' alternative conceptions (Meyer 2004).

Therefore, in this study, we sought to investigate elementary school teachers' knowledge about their students' conceptions on chemistry topics, and thus we examined both students' alternative conceptions and teachers' awareness of their students' alternative conceptions on selected topics. Another purpose of this study is to explore teachers' characteristics influencing their awareness of students' alternative conceptions. Based on a synthesis of the research evidence cited in the relevant literature, we selected several variables which might be related to teachers' development of PCK: teaching experience, academic degree, science teaching efficacy, and constructivist and traditional views about teaching and learning. These variables are discussed below. 
Previous studies have reported that experienced teachers possess more PCK and are more knowledgeable about students' difficulties than novice teachers (Akerson et al. 2000; Angell et al. 2005; Hogan et al. 2003). In addition, experienced teachers think of students' prior knowledge as a bridge to integrating new information to create better explanations (Meyer 2004). Therefore, it might be assumed that experienced teachers would be more effective than novice teachers in adjusting the process of science instruction on the bases of their knowledge about students' conceptions. However, it was reported that experienced teachers showed no supremacy over their counterparts in understanding students' conceptions in some studies (Caillods et al. 1997; Diakidoy and Iordanou 2003). Therefore, it is reasonable to consider teachers' level of professional experience as a factor that might influence their awareness of students' alternative conceptions.

Teachers' voluntary pursuit of opportunities for their professional development, such as taking graduate courses, might be another factor. Darling-Hammond (2000) reported that there is a positive relationship between education training and teacher effectiveness. Courses taken in science education also appeared to have a positive impact on teacher effectiveness (Chaney 1995; Monk 1994). In addition, certification status, degree completion, and graduate and undergraduate courses taken have been used as the evidence of teachers' pedagogical preparation (Moyer-Packenham et al. 20o8). Teachers' highest academic degree, therefore, might be considered as a variable that influences their awareness of students' alternative conceptions.

Previous studies also have indicated teachers' level of self-efficacy to be one of the important factors influencing the characteristics of their pedagogical practice (Bandura 1997; Bleicher 2004). Self-efficacy should be defined as teachers' belief that students' learning can be influenced by effective teaching and as teachers' confidence in their own teaching abilities (Enochs et al. 2000; Tschannen-Moran and Hoy 2001). It was reported that teachers' PCK is significantly related to their science teaching efficacy belief (Lim 2003). There is also ample evidence that teachers with high self-efficacy tend to use more student-centered teaching strategies (Enochs et al. 1995; Lumpe et al. 2000; Marshall et al. 2009) and tend to be more effective and to spend more time with their students in supporting them (Guskey 1988; Marshall et al. 2009). Therefore, it might be reasonable to regard teachers' 
science teaching efficacy belief as an important factor influencing their ability to identify students' alternative conceptions.

Finally, it has been reported that teachers' belief about their preferred ways of teaching and learning could influence their teaching behaviors (Brown and Rose 1995; Chan and Elliott 2004; Kang and Wallace 2005; Zohar 2004). Previous studies generally suggested that there are two distinctive perspectives to view teaching and learning: a traditional view and a constructivist view (Adams and Krockover 1997; Hashweh 1996). From the traditional view, teaching and learning are regarded as the transfer of knowledge from a teacher to a learner. From the constructivist view, on the other hand, teaching and learning are considered to be the active process of a knowledge construction by the learner. Making students' existing conceptions explicit and thus creating a state of cognitive disequilibrium has been widely considered to be the starting point of the knowledge reconstruction process (Linnenbrink and Pintrich 2003; Vosniadou 2003; Wandersee et al. 1994). Therefore, teachers possessing the constructivist view about teaching and learning are much more likely to seek to identify and to be aware of their students' alternative conceptions. They also believe that knowledge of students' alternative conceptions is a prerequisite for creating an effective learning environment in which the alternative conceptions are no longer viable, and thus a reconstruction of students' conceptions can be fostered. Therefore, a teacher's view toward teaching and learning should be considered as a possible factor to influence their awareness of students' alternative conceptions.

\section{Methods}

Participants

The participants in this study were 163 elementary school teachers and 532 sixth graders (12- or 13-years old) from 16 elementary schools in the Gyeonggi province of Korea. Although the sample for this study was selected from schools in eight school districts of the Gyeonggi province, which is composed of 25 school districts, we did not perceive it to be a likely threat to the representativeness of the selected sample because virtually every school in Korea, except for a few special schools, follows the National Curriculum. This near fidelity to the 
National Curriculum results in homogeneous teaching and learning in terms of quantity as well as quality. The report of the Ministry of Education, Science, and Technology also indicated that schools in Korea are generally quite homogeneous in terms of their academic standards (MEST 2009).

All teachers possessed science teaching experience. From an original pool of 163 teachers, we included 152 subjects (50 males and 102 females) in this study. Eleven teachers were ineligible because parts of their answers to at least one of the tests were judged to be inadequate to be analyzed. The mean age of the teachers was 36.9-years old $(\mathrm{SD}=7.7)$ and the average of their teaching experience was 12.1 years $(\mathrm{SD}=8.2)$.

We selected one 6th-grade class per each elementary school from which the teachers were sampled. We chose sixth graders because the concepts of change of states and dissolution, which were selected as the target concepts in this study, are respectively taught at the $4^{\text {th }}$ and 5th grade according to the National Science Curriculum of Korea. From an original pool of 532 students, the subjects included in this study were 529 students (270 boys and 259 girls) after eliminating those who did not respond to one of the critical study measures.

\section{Target Concepts}

With respect to choosing concepts to examine in this study, three criteria were considered. First, we focused on concepts related to the super-ordinate chemical term "substance" because understanding the properties of a "substance" is a prerequisite for grasping a number of interrelated scientific ideas in chemistry (Johnson 1997; Rahayu and Tytler 1999). The importance of the substance concept is further corroborated by the fact that research on students' conceptions about the substance concept rapidly expanded during the past decade and remains an important agenda to be investigated (e.g., Barker 2002; Driver et al. 1994a; Garnett et al. 1995). Next, we needed concepts that have been documented in depth concerning the characteristic features of students' conceptions because, considering the purpose of this study, teachers should have opportunities for obtaining specific knowledge about these conceptions through their experiences. Finally, the concepts needed to be integrated within the National Science Curriculum of Korea. According to the Korean National Science Curriculum, 
the particulate nature of matter should not be introduced at the elementary school level. Therefore, various natural phenomena and related concepts in elementary science textbooks are not explained from a microscopic perspective (i.e., introducing particles such as atoms and molecules) but only from a macroscopic perspective. Among the concepts satisfying all of our criteria, we chose change of states and dissolution as the target concepts of this study.

\section{Instruments}

Conceptions Test

A conceptions test was developed in order to examine students' ideas about change of states and dissolution. If we develop new items to reveal students' conceptions, teachers might not have enough opportunities for obtaining specific knowledge about these conceptions through their experiences. In order to avoid this potential problem, the items of the conceptions test were developed giving close consideration to several relevant previous studies (Bar and Travis 1991; Hatzinikita and Koulaidis 1997; Holding 1987; Johnson 1998; Noh and Kim 1996; Osborne and Cosgrove 1983; Stavy 1990). Three items, which respectively ask students about vaporization, conservation of mass during vaporization, and condensation, were selected for examining students' conceptions about change of states. Two items concerning conservation of mass during dissolution and homogeneity of a solution were also included to scrutinize students' conceptions about dissolution.

Previous research has indicated that multiple-choice format might distort the distribution of students' responses to a conception test (Bar and Travis 1991; Staver and Pascarella 1984). That is, when students find themselves in a situation where they are not sure what the right answer is, they might be distracted toward alternative conceptions that seem scientific. Certain types of conceptions, as a result, are rarely found in an open-ended format test, but might be erroneously regarded as prevailing alternative conceptions among students responding to a multiple-choice format test. In order to avoid this problem, we made each option for the items without including additional information that might distract students' attention (see in Questions 2, 4, and 5 in Appendix). Students were asked to respond to an 
accompanying open-ended section for each item in order to collect information about the rationales for their answers. The other two items (Questions 1 and 3) are solely made in an open-ended format. A full delineation of the conceptions test is given in Appendix.

Test of the Understanding About Students' Conceptions

A test was also developed to evaluate teachers' understanding about students' ideas regarding the target concepts. The test was devised to collect information about teachers' predictions of the existence and the likely percentage distribution of their students' conceptions. Teachers were asked to write in detail both the scientifically accepted conception and all possible students' alternative ones after presenting them with the same questions that had been administered to their students. An example of an item used to assess a given target concept is presented in Fig. 1.

\begin{tabular}{|l|l|}
\hline $\begin{array}{l}\text { A glass is filled with ice cubes. The lid is closed tightly and the outer surface of the glass is dried with a towel. } \\
\text { After fifteen minutes, the outer surface of the glass is wet. Where do the drops on the outer surface of the glass } \\
\text { come from? }\end{array}$ & \begin{tabular}{c} 
Percentage \\
\hline Scientific conception $\%$
\end{tabular} \\
\hline Possible student alternative conceptions & Percentage \\
\hline & $(\quad) \%$ \\
\hline & $(\quad) \%$ \\
\hline
\end{tabular}

Fig. 1. A sample item of the test of the understanding of students' conceptions. 
Science Teaching Efficacy Belief Questionnaire

The teachers' self-efficacy for science teaching was measured with the items from the Science Teaching Efficacy Belief Instrument (STEBI; Riggs and Enochs 1990). The STEBI has two subscales, the science teaching outcome expectancy (12 items) and the personal science teaching efficacy belief (13 items). These two dimensions of teacher self-efficacy were validated as discrete constructs through a factor analysis (Riggs and Enochs 1990), and have been consistently found to be independent (Woolfolk Hoy and Burke-Spero 2005). The STEBI asks teachers to rate each statement on a five-point Likert scale. The translation of the items of the STEBI was verified by three independent science educators fluent in English. Cronbach's internal consistency reliability coefficients of the science teaching outcome expectancy subscale and the personal science teaching efficacy belief subscale were reported as 0.77 and 0.92, respectively (Riggs and Enochs 1990). In this study, the internal consistency reliability coefficients for the two subscales were determined to be 0.69 and 0.83 , respectively.

Views Toward Teaching and Learning Questionnaire

Teachers' views toward teaching and learning were measured with the Teaching Learning Conceptions Questionnaire (TLCQ; Chan and Elliott 2004). The TLCQ consists of 30 items related to issues such as the meaning of learning and teaching, the roles of teachers and students in learning and teaching, class management, and teaching and learning strategies. These items were distributed within the questionnaire to represent either a traditional view subscale (18 items) or a constructivist view subscale (12 items). Teachers were asked to respond to each item on a five point Likert scale. The translation of the items of the TLCQ was also verified by three independent science educators fluent in English. Chan and Elliott (2004) reported the Cronbach's internal consistency reliability coefficient of both subscales of the TLCQ as 0.84 . In this study, the internal consistency reliability coefficients for the two subscales were determined to be 0.85 (traditional view) and 0.78 (constructivist view), respectively. 


\section{Procedure}

A panel of experts consisting of three science educators and five elementary school teachers verified the face validity of the conceptions test and the test of the understanding about students' conceptions. Pilot administrations of both tests were conducted in order to examine the effectiveness of the tests in probing students' and teachers' ideas. A few minor problems, such as the readability of the tests and the format of an answer sheet, were detected. The tests were appropriately modified through intensive discussions with the expert panel.

All students completed the conceptions test at the end of the spring semester. Students were informed before administrating the conceptions test that their course grades would not be affected by the results of the test. They were also instructed to read each question carefully and to write in detail their thoughts including the rationales. The test of the understanding about students' conceptions, the science teaching efficacy belief questionnaire, and the views toward teaching and learning questionnaire were administered to the teachers at the end of the spring semester.

Students' responses to each item of the conceptions test were classified considering both the option they chose, if any, and the rationales they conveyed. Possible students' conceptions mentioned from teachers' responses to each item of the test of the understanding about students' conceptions were also classified. The coding schemes for both students' and teachers' responses were derived empirically through an iterative process-reading their responses, categorizing them, and revising the categories. Then, two coding schemes were combined to devise an integrated coding scheme for comparing students' conceptions with teachers' predictions of them. After a temporary coding scheme was agreed upon, two raters independently classified a subset of randomly selected responses. Discrepancies between the raters were then discussed and resolved. This discussion/resolution procedure was repeated before the intercoder agreement, calculated by computing a ratio of agreement to all codes in each item, reached above $90 \%$. Then, one rater classified all the responses again while the other rater independently checked the classifications.

A few students did not respond to some questions; these responses were classified as "no response." Other responses, whose meaning 
was difficult to grasp (due to reiteration, inconsistencies, and/or insufficient information), were coded as "unclassified." Some teachers did not provide rationales to their responses, especially with respect to Questions 2, 4, and 5. The percentages of these responses ranged from 12.9 to $23.8 \%$ of the total responses (depending on the question). Without specific rationales, it was difficult to infer what types of conceptions the teachers would know or predict. Therefore, we classified them as "no reason" and excluded them from the deliberation of teachers' awareness of their students' conceptions.

Teachers are generally anticipated to recognize their students' representative alternative conceptions, not all possible alternative conceptions. Therefore, we focused on the alternative conceptions held by more than $10 \%$ of the student subjects and classified them as major alternative conceptions. For analyzing the relationship between teachers' characteristics and their awareness of students' alternative conceptions, we set the total number of students' major alternative conceptions correctly predicted by each teacher in five items of the conceptions test as a criterion for the degree of the teachers' awareness of students' alternative conceptions. Thus, 19 teachers who had not responded to all items in the test of the understanding about students' conceptions were excluded from subsequent analyses.

On analyzing teachers' characteristics variables, we divided teachers into two groups (high and low levels) in terms of their teaching experience, academic degree, science teaching efficacy, and constructivist and traditional views about teaching and learning, respectively. According to a criterion suggested in previous studies (Germann and Barrow 1995; Noh et al. 2004), we classified the teachers who had less than 5 years of teaching experience as novice teachers (low level) and the others as experienced teachers (high level). The teachers who had only a bachelor's degree were classified into one group (low level) and those who had a master's degree were classified into the other group (high level). Teachers were also classified into either a low level or a high level group on the bases of the median scores of the two subscales of the science teaching efficacy belief questionnaire (i.e., science teaching outcome expectancy and personal science teaching efficacy belief) and the two subscales of the views toward teaching and learning questionnaire (i.e., traditional view and constructivist view), respectively. 
Table 1. Student responses and teacher predictions about students' conceptions: Question 1

\begin{tabular}{lccc} 
& $\begin{array}{c}\text { Numbers of } \\
\text { students }(\%) \\
(N=510)\end{array}$ & $\begin{array}{c}\text { Numbers of } \\
\text { teachers }{ }^{\mathrm{a}}(\%) \\
(N=140)\end{array}$ & $\begin{array}{c}\text { Means of } \\
\text { teachers' } \\
\text { predictions }\end{array}$ \\
\hline Air & $302(59.2)$ & $141(100.7)$ & 38.7 \\
$\quad$ Dissolved in water (1A) & $117(22.9)$ & $54(38.6)$ & 42.0 \\
From the outside (1B) & $31(6.1)$ & $32(22.9)$ & 25.3 \\
Made by heat (1C) & $15(2.9)$ & $10(7.1)$ & 21.0 \\
Unspecified sources & $139(27.3)$ & $45(32.1)$ & - \\
Water vaporb (1D) & $158(31.0)$ & $107(76.4)$ & 40.0 \\
Water (1E) & $12(2.4)$ & $59(42.1)$ & 27.8 \\
Heat (1F) & $2(0.4)$ & $7(5.0)$ & 15.0 \\
Hydrogen and oxygen $(1 \mathrm{G})$ & $1(0.2)$ & $2(1.4)$ & 4.0 \\
Others & $10(2.0)$ & $32(22.9)$ & - \\
Unclassified & $25(4.9)$ & $39(27.9)$ & - \\
Total & $510(100.0)$ & 387 & - \\
\hline
\end{tabular}

a. Multiple responses are included

b. Scientific conception

\section{Results}

\section{Students' Responses and Teachers' Predictions about Students' Conceptions}

\section{Vaporization}

For the item concerning the matter inside the bubbles of boiling water (Question 1), students' and teachers' responses were classified into five categories: air, water vapor, water, hydrogen and oxygen, and heat. The frequencies of students and teachers in each response category and the means of teachers' predictions are summarized in Table 1.

Seventy-six percent of the teachers predicted that $40 \%$ of the students would possess the scientific conception, whereas it was found that only $31 \%$ actually exhibited the scientific conception. The most prevailing alternative conception among the students was "air" which was also reported as one of the widely held alternative conceptions in previous studies (Hatzinikita and Koulaidis 1997; Johnson 1998; Osborne and Cosgrove 1983). Although many teachers seemed to 
correctly predict the existence of this alternative conception, they had difficulty in predicting the specific features of it. For example, 39 and $23 \%$ of the teachers overestimated the percentages of the students possessing the alternative conceptions that the air inside the bubbles comes from water $(1 \mathrm{~A})$ and from outside (1B), respectively. Furthermore, $42 \%$ of the teachers predicted that $28 \%$ of the students have the alternative conception that the matter inside of the bubble is water (1E), whereas only $2 \%$ of the students were found to actually possess this alternative conception. Osborne and Cosgrove (1983) reported that about $40 \%$ of the students thought that the matter inside the bubbles is hydrogen and oxygen gases $(1 \mathrm{G})$, and another $30 \%$ thought that the matter is heat $(1 \mathrm{~F})$. Hatzinikita and Koulaidis (1997) also reported about $20 \%$ of the students hold the "hydrogen and oxygen" alternative conception. In this study, however, few students were found to possess these alternative conceptions and only a minority of teachers also predicted them as possible students' alternative conceptions.

Not only the students but also the teachers were found to possess alternative conceptions. Twenty-nine percent of the teachers were not able to exhibit the scientific conception, and some of them even were found to regard the scientific conception as an alternative conception. Most teachers holding alternative conceptions (22\%) suggested the "air" alternative conception as the scientific conception.

\section{Conservation of Mass During Vaporization}

Students' responses and teachers' predictions for the item concerning the conservation of mass during the change of state from water into vapor in a closed system (Question 2) are presented in Table 2.

Forty percent of the students were found to have a scientific conception (2A) and most teachers correctly predicted the existence of this conception. However, the teachers failed to correctly predict their students' alternative conceptions. The two most prevalent alternative conceptions among the students were "liquid weighs more than gas (2B, $19 \%)$ )" and "the volume of vapor increases (2E, $19 \%$ )," whereas the percentages of the teachers who predicted the existence of those conceptions were only 32 and $56 \%$, respectively. Furthermore, some teachers (33\%) even surmised that the students might have the alternative conception of "water disappears into the air" $(2 \mathrm{C})$ which actually few students (3\%) were found to possess. 
Table 2. Student responses and teacher predictions about students' conceptions: Question 2

\begin{tabular}{lccc} 
& $\begin{array}{c}\text { Numbers of } \\
\text { students }(\%) \\
(N=525)\end{array}$ & $\begin{array}{c}\text { Numbers of } \\
\text { teachers }{ }^{\mathrm{a}}(\%) \\
(N=145)\end{array}$ & $\begin{array}{c}\text { Means of } \\
\text { teachers' } \\
\text { predictions }\end{array}$ \\
\hline Same $^{\mathrm{b}}$ & $222(42.3)$ & $149(102.8)$ & 47.7 \\
Water only changes its state (2A) & $212(40.4)$ & $142(97.7)$ & 48.7 \\
Others & $10(1.9)$ & $7(4.8)$ & - \\
Decrease & $137(26.1)$ & $135(93.1)$ & 25.2 \\
Liquid weighs more than gas (2B) & $99(18.9)$ & $46(31.7)$ & 25.5 \\
Water disappears into the air (2C) & $15(2.9)$ & $48(33.1)$ & 23.5 \\
Vapor has no weight (2D) & $10(1.9)$ & $6(4.1)$ & 29.8 \\
Others & $13(2.5)$ & $13(9.0)$ & - \\
No reason & - & $22(15.2)$ & - \\
Increase & $111(21.1)$ & $110(75.9)$ & 27.3 \\
The volume of vapor increases (2E) & $102(19.4)$ & $81(55.9)$ & 26.8 \\
Others & $9(1.7)$ & $6(4.1)$ & - \\
No reason & - & $23(15.9)$ & - \\
Unclassified & $55(10.5)$ & $19(13.1)$ & - \\
Total & $525(100.0)$ & 413 & - \\
\hline
\end{tabular}

a. Multiple responses are included

b. Scientific conception

\section{Condensation}

In Question 3, subjects were asked about a situation in which liquid drops formed on the outer surface of a cup containing ice cubes. Both the students' speculations about the source of liquid drops and the teachers' predictions about them were diverse, such as ice inside the cup, water vapor in the air, air inside/outside the cup, and coldness from the ice. The frequencies of students and teachers in each response category and the means of teachers' predictions are presented in Table 3.

About $76 \%$ of the teachers predicted that more than half of the students would possess a scientific conception (3C), whereas only $18 \%$ of the students were found to actually hold it. The alternative conceptions that the liquid drops come from ice ( $3 \mathrm{~A}$ and $3 \mathrm{~B}$ ) were the most prevalent ones among the students. These conceptions were reported as major alternative conceptions by previous studies (Hatzinikita and Koulaidis 1997; Osborne and Cosgrove 1983). However, teachers were 
Table 3. Student responses and teacher predictions about students' conceptions: Question 3

\begin{tabular}{|c|c|c|c|}
\hline & $\begin{array}{c}\text { Numbers of } \\
\text { students } \\
(\%) \\
(N=510)\end{array}$ & $\begin{array}{c}\text { Numbers of } \\
\text { teachers } \\
(\%) \\
(N=149)\end{array}$ & $\begin{array}{c}\text { Means of } \\
\text { teachers' } \\
\text { predictions }\end{array}$ \\
\hline Ice & $195(38.2)$ & $120(80.5)$ & $35 \cdot 3$ \\
\hline Water from melted ice (3A) & $97(19.0)$ & $114(76.5)$ & $35 \cdot 7$ \\
\hline Air from ice (3B) & $98(19.2)$ & $6(4.0)$ & 26.9 \\
\hline Water vapor in the $\operatorname{air}^{b}(3 \mathrm{C})$ & $94(18.4)$ & $113(75.8)$ & 53.8 \\
\hline Air & $92(18.0)$ & $39(26.2)$ & 51.7 \\
\hline From the outside (3D) & $78(15 \cdot 3)$ & $35(23.5)$ & 56.1 \\
\hline From the inside of the cup $(3 \mathrm{E})$ & $14(2.7)$ & $4(2.7)$ & 13.8 \\
\hline Coldness (3F) & $32(6.3)$ & - & - \\
\hline Others & $49(9.6)$ & $23(15 \cdot 4)$ & - \\
\hline Unclassified & $48(9.4)$ & $26(17.4)$ & - \\
\hline Total & $510(100.0)$ & 321 & - \\
\hline
\end{tabular}

a Multiple responses are included

b Scientific conception

found to lack thorough understanding about the specific features of students' alternative conceptions. That is, $77 \%$ of the teachers predicted that $36 \%$ of the students would think that liquid drops are water originating from the melted ice $(3 \mathrm{~A})$ but those who possessed this alternative conceptions were only $19 \%$. In addition, $19 \%$ of the students regarded the air from the ice as the source of liquid drops (3B), whereas the teachers who predicted the existence of this alternative conception were only $4 \%$. Liquid drops come from the air outside the cup (3D) is another widely held alternative conception by the students $(15 \%)$. However, the existence of this alternative conception was predicted by only $24 \%$ of teachers and their prediction of the distribution (56\%) was also far from the actual. Previous studies (Hatzinikita and Koulaidis 1997; Osborne and Cosgrove 1983) reported that approximately $10-15 \%$ of the students hold the alternative conception that liquid drops are formed from the coldness of ice (3F). The results of this study, however, showed that only a few students (6\%) possess this alternative conception and the teachers did not regard it as a possible alternative conception.

Meanwhile, only $75 \%$ of the teachers were found to have a scientific conception. The majority of the rest (21\%) thought that the air from outside forms liquid drops. 
Table 4. Student responses and teacher predictions about students' conceptions: Question 4

\begin{tabular}{|c|c|c|c|}
\hline & $\begin{array}{c}\text { Numbers of } \\
\text { students } \\
(\%) \\
(N=515)\end{array}$ & $\begin{array}{c}\text { Numbers of } \\
\text { teachers }^{\mathrm{a}} \\
(\%) \\
(N=149)\end{array}$ & $\begin{array}{c}\text { Means of } \\
\text { teachers' } \\
\text { predictions }\end{array}$ \\
\hline Sameb & $345(67.0)$ & $150(100.7)$ & 59.8 \\
\hline Sugar just dissolves in water $(4 \mathrm{~A})$ & $318(61.7)$ & $147(98.7)$ & 60.6 \\
\hline Others & $27(5.2)$ & $3(3.4)$ & - \\
\hline Increase & $97(18.8)$ & $79(53.0)$ & 18.6 \\
\hline Sugar is added $(4 \mathrm{~B})$ & $73(14.2)$ & $20(13.4)$ & 13.5 \\
\hline The volume of water increases $(4 \mathrm{C})$ & $13(2.5)$ & $13(8.7)$ & 24.6 \\
\hline Others & $9(1.7)$ & $13(8.7)$ & - \\
\hline No reason & $2(0.4)$ & $33(22.1)$ & - \\
\hline Decrease & $54(10.5)$ & $141(94.6)$ & 27.8 \\
\hline Sugar disappears (4D) & $33(6.4)$ & $71(47.7)$ & 30.3 \\
\hline Sugar becomes lighter (4E) & $16(3.1)$ & $9(6.0)$ & 21.6 \\
\hline Others & $4(0.8)$ & $20(13.4)$ & - \\
\hline No reason & $1(0.2)$ & $41(27.5)$ & - \\
\hline Unclassified & $19(3.7)$ & $13(8.7)$ & - \\
\hline Total & 515 (100.0) & 383 & - \\
\hline
\end{tabular}

a. Multiple responses are included

b. Scientific conception

\section{Conservation of Mass During Dissolution}

Students' responses and teachers' predictions to Question 4, in which students were asked to predict the mass of the sugar solution after completely dissolving sugar in water, were classified into several categories. The frequencies of students and teachers in each response category and the means of teachers' predictions are summarized in

\section{Table 4 .}

Many students ( $62 \%$ ) were found to possess a scientific conception concerning the conservation of mass during dissolution (4A). Most teachers correctly predicted the percentage of the students holding a scientific conception. However, they did not successfully predict the distribution of their students' alternative conceptions. Holding (1987) reported students tend to think that the mass of the solution would decrease because sugar disappears after dissolution (4D). About half of the teachers in this study predicted that $30 \%$ of the students hold this alternative conception, whereas only $6 \%$ of the students actually 
Table 5. Student responses and teacher predictions about students' conceptions: Question 5

\begin{tabular}{lccc} 
& $\begin{array}{c}\text { Numbers of } \\
\text { students } \\
(\%) \\
(N=522)\end{array}$ & $\begin{array}{c}\text { Numbers of } \\
\text { teachers } \\
(\%) \\
(N=148)\end{array}$ & $\begin{array}{c}\text { Means of } \\
\text { teachers' } \\
\text { predictions }\end{array}$ \\
\hline Bottom of the solution & $311(59.6)$ & $141(95.3)$ & 35.5 \\
Dissolved salt exists at the bottom (5A) & $157(30.1)$ & $83(56.1)$ & 36.8 \\
Undissolved salt sinks at the bottom (5B) & $127(24.3)$ & $9(6.1)$ & 25.6 \\
Salt dissolves at the bottom (5C) & $23(4.4)$ & $10(6.8)$ & 28.7 \\
Others & $4(0.8)$ & $2(1.4)$ & - \\
No reason & - & $37(25.0)$ & - \\
Equal & $169(32.4)$ & $148(100.0)$ & 53.7 \\
Sugar solution is homogeneous (5D) & $162(31.0)$ & $144(97.3)$ & 54.6 \\
Others & $7(1.3)$ & $4(2.7)$ & - \\
Upper part of the solution & $6(1.1)$ & $71(48.0)$ & 13.3 \\
Dissolved salt floats around the surface (5E) & $2(0.4)$ & $22(14.9)$ & 14.6 \\
Others & $4(0.8)$ & $21(14.2)$ & - \\
No reason & - & $29(19.6)$ & - \\
Middle of the solution & - & $32(21.6)$ & 10.7 \\
Unclassified & $36(6.9)$ & $20(13.5)$ & - \\
Total & 522 & $(100.0) 413$ & - \\
\hline
\end{tabular}

a. Multiple responses are included

b. Scientific conception

exhibited it. On the contrary, the most prevalent alternative conception among the students was that the mass of the solution would increase because sugar was added (4B, $14 \%)$, and it was correctly predicted by only $13 \%$ of the teachers.

\section{Homogeneity of a Solution}

In Question 5, students were asked to predict which part of the solution would be the saltiest after completely dissolving salt in water. The students' responses and teachers' predictions were classified into several categories. The frequencies of students and teachers in each response category and the means of teachers' predictions are presented in Table 5.

Although most teachers predicted the existence of the scientific conception (5D) among their students, they overestimated the percentage of it. They predicted that $54 \%$ of the students might hold the 
Table 6. $T$-test results on the number of correctly predicted alternative conceptions by level of teacher characteristics

\begin{tabular}{llllll} 
Variable & Mean & (SD) & $t$ & df & $p$ \\
\hline & Low & High & & & \\
Teaching experience & $2.70(1.66)$ & $2.66(1.39)$ & 0.132 & 131 & 0.895 \\
Academic degree & $2.75(1.54)$ & $2.51(1.25)$ & 0.898 & 131 & 0.371 \\
Science teaching efficacy & & & & & \\
$\quad$ Outcome expectancy & $2.78(1.55)$ & $2.62(1.43)$ & 0.595 & 131 & 0.553 \\
$\quad$ Personal efficacy belief & $2.79(1.51)$ & $2.61(1.48)$ & 0.712 & 131 & 0.478 \\
Constructivist view about teaching and learning & $2.71(1.54)$ & $2.62(1.35)$ & 0.377 & 131 & 0.707 \\
Traditional view about teaching and learning & $3.06(1.27)$ & $2.27(1.52)$ & 3.241 & 131 & $0.002^{* *}$ \\
\hline
\end{tabular}

${ }^{* *} p<0.01$

scientific conception, whereas only $32 \%$ actually exhibited it. More than half of the teachers correctly predicted that the existence of the alternative conception of "more dissolved salt exists at the bottom" (5A) but only a few teachers (6\%) were aware of the alternative conception of "undissolved salt sinks at the bottom" (5B), which was another prevailing alternative conception among the students. In addition, $48 \%$ of the teachers predicted students would think that the upper part of the solution is the saltiest and $22 \%$ of the teachers, on the other hand, predicted students would think that the middle of the solution is the saltiest. However, few students actually hold these ideas, which was consistent with the previous studies investigating Korean students' conceptions concerning dissolution (Kim and Lee 1998; Noh and Kim 1996).

Factors Influencing Teachers' Awareness of Students' Conceptions

In order to investigate the effects of teachers' characteristics on their awareness of students' alternative conceptions, we divided teachers into two groups (high and low levels) in terms of their teaching experience, academic degree, science teaching efficacy (outcome expectancy and personal efficacy belief), and constructivist and traditional views about teaching and learning, respectively. Then, we compared the means of the numbers of correctly predicted major alternative conceptions by each group of teachers using independent sample t-tests (Table 6). 
There was no statistically significant difference between experienced and novice teachers in predicting major alternative conceptions. Teachers' academic degree was also found not to be significantly related to the numbers of correctly predicted major alternative conceptions. The differences between the numbers of correctly predicted major alternative conceptions by high level and low level teachers were also found not to be significant in both the subscales of science teaching efficacy belief. The difference between the high and the low groups in terms of constructivist view about teaching and learning in predicting major alternative conceptions was not statistically significant. On the contrary, the difference between the high and the low groups was statistically significant in the analysis of the effect of teachers' traditional view about teaching and learning on predicting major alternative conceptions ( $p \backslash 0.01)$. That is, teachers who possess relatively less traditional views about teaching and learning were found to be more acutely aware of their students' major alternative conceptions than their counterpart.

\section{Discussion}

Although there has been tremendous speculation about students' alternative conceptions, little attempt has been made to translate these speculations into practical tools for the real world of elementary school science. Knowledge, about the alternative conceptions which students bring to science classes, is important because it can provide teachers with invaluable information about students' difficulties in attaining new concepts and consequential effective approaches for assisting their students to overcome these difficulties. In this study, therefore, we sought to investigate elementary school teachers' awareness of their students' alternative conceptions.

The results of this study indicated that the teachers overestimated the number of students holding accurate scientific conceptions by 9-36\% in each of the study questions except for the one concerning dissolution (Question 4). Watts and Zylbersztajn (1981) reported similar results in the study of five physics teachers' predictions about their students' conceptions about force. Diakidoy and Iordanou (2003) also reported that more than half of elementary school teachers tended to overestimate students' knowledge and understanding of the energy 
concept. The tendency for teachers to overestimate the existence of a scientific conception among their students might be an obstacle to an effective science instruction in that they are less likely to: (1) devote significant time and effort to encouraging students to realize their own alternative conceptions, (2) present appropriate discrepant events to arouse students' cognitive conflict, and (3) help students reconstruct their cognitive structure.

On analyzing students' responses to the conceptions test, various kinds of alternative conceptions about change of states and dissolution were found to exist. Although there were some unique alternative conceptions found only among the students participating in this study, such as regarding the source of liquid drops as the air from the ice $(3 \mathrm{~B}, 19 \%)$ or the air outside the cup (3D, $15 \%)$ and believing the total mass increases during dissolution because of added sugar $(4 \mathrm{~B}$, $14 \%$ ), most of the alternative conceptions were more or less similar with those previously reported in the literature. From the constructivist's viewpoint, teachers should have knowledge about their students' alternative conceptions in order to effectively manage students' alternative ideas, and subsequently to introduce an accurate scientific concept. Gomez-Zwiep (2008) reported that one third of elementary teachers were unable to produce even one example of students' alternative conceptions. In this study, however, it was found that teachers who were not able to mention any instance of students' alternative conceptions were less than $10 \%$ and the rest of teachers predicted, on average, 1.6 student alternative conceptions for each question.

As stated earlier, we decided to focus on the teachers' awareness of the nine major alternative conceptions $(1 \mathrm{~A}, 2 \mathrm{~B}, 2 \mathrm{E}, 3 \mathrm{~A}, 3 \mathrm{~B}, 3 \mathrm{D}, 4 \mathrm{~B}, 5 \mathrm{~A}$, and $5 \mathrm{~B}$ ), which were indicated to be held by more than $10 \%$ of students because it might be impossible for teachers to completely grasp all kinds of alternative conceptions possessed by the students. There were wide variations, from 4 to $77 \%$, in the ratios of the teachers who correctly predicted the existence of the major alternative conceptions. However, less than $40 \%$ of teachers, at least, were found to know the prevalence of students' alternative conceptions in six out of nine major alternative conceptions except for $2 \mathrm{E}, 3 \mathrm{~A}$, and $5 \mathrm{~A}$. They also failed to predict the distribution of major alternative conceptions. That is, they tended to overestimate the ratios of the students possessing alternative conceptions-the differences between their expectations and reality were substantial, $17-41 \%$, in three major alternative conceptions 
(1A, 3A, and 3D). Furthermore, many teachers expected the presence of certain alternative conceptions which were hardly found among their students; the matter inside the bubbles of boiling water is the air from outside (1B, $23 \%$ ) and water (1E, $42 \%$ ); mass decreases during the change of state from water into vapor because water disappears into the air $(2 \mathrm{C}, 33 \%)$; the total mass decreases during dissolution because sugar disappears (4D, $48 \%$ ); the upper part of the salt solution is the saltiest because dissolved salt floats around the surface (5E, $15 \%$ ). To sum up, teachers in this study generally do not have sufficient knowledge about students' alternative conceptions.

One could suppose that this inconsistency might be due to the fact that teachers' knowledge about students' alternative conceptions was not obtained from their actual teaching experience during science classes but was originated from their learning in the courses of preservice teacher programs and/or in-service training. As reported in the literature, much effort has been exerted in order to develop specific teacher preparation programs which focus on increasing teachers' PCK, including the understanding of students' prior knowledge (e.g., Davis and Smithey 2009; Mellado et al. 1998; Otero and Nathan 2008; Pringle 2006), and this might provide the teachers with the knowledge about students' alternative conceptions. However, five out of 12 alternative conceptions ( $1 \mathrm{E}, 2 \mathrm{C}, 3 \mathrm{D}, 4 \mathrm{~B}$, and $5 \mathrm{E}$ ), which more than $10 \%$ of teachers expected to be prevalent among their students, have not been reported in previous studies. In addition, there were a considerable number of teacher responses, 31-51\% depending on the question, that we classified as "others" and "unclassified," which also could be regarded as not among the commonly found alternative conceptions reported in the literature. Furthermore, there were five alternative conceptions which were predicted by less than $10 \%$ of teachers $(1 \mathrm{~F}, 1 \mathrm{G}, 2 \mathrm{D}, 3 \mathrm{~F}$, and $4 \mathrm{E})$ though they were reported as representative alternative conceptions in the literature. To sum up, these results are not consistent with the supposition that teachers might have attained the knowledge about students' alternative conceptions during pre-service and/or in-service training. Then, on what bases did the teachers predict students' alternative conceptions?

One possible explanation might be that teachers' predictions were made on the basis of their knowledge about the general characteristics of alternative conceptions, such as the known sources and the common features of students' alternative conceptions. First, teachers seem 
to surmise that students' everyday experience might influence their alternative conceptions. For example, the teachers' predictions that the matter inside the bubbles of boiling water is air (1A and $1 \mathrm{~B})$ might stem from students' everyday experience about the air bubbles of an aquarium. The alternative conceptions that liquid weighs more than gas (2B), that the source of liquid drops is the water from melted ice (3A), and that more dissolved salt exists at the bottom of a solution (5A) were also likely to be derived from students' everyday experiences about the rising bubbles in drinks, ice melting into water, and undissolved sugar or salts at the bottom, respectively. It was reported that teachers have a tendency to attribute students' alternative conceptions to faulty or erroneous information that students acquire from their experiences with objects and events and/or their indirect experiences from parents, friends, museums, and various kinds of media including newspapers, cartoons, books, magazines, television, movies, computer games, the Internet, and so forth (Gomez-Zwiep 2008; Meyer 2004).

Next, teachers seem to consider the possibility that students' perceptually dominant thinking (Driver et al. 1985) might be conducive to the formation of their alternative conceptions. For example, both the alternative conceptions that water disappears into the air (2C) and the volume of vapor increases after a vaporization of water (2E) might be the results of teachers' consideration of students' perceptually dominant thinking of observed phenomena. The alternative conceptions of the mass increase by added sugar (4B) and the mass decrease on the basis of disappearing sugar (4E) also might be predicted in the same manner.

Finally, teachers' predictions might be led by their forced efforts to deliberate all possible answers through inferential reasoning in a given situation. For example, not a few teachers expected that students would think that either the upper part or the middle of salt solution is the saltiest in Question 5 without providing any reasonable rationales. They seemed to list these responses not on the basis of their knowledge about students' alternative conceptions but from considering all possible occasions. Although this kind of prediction might accidentally coincide with students' actual alternative conceptions at times, it should be meaningless for teachers to predict students' alternative conceptions just through inferential reasoning because it could not provide teachers any practical information about planning and implementing effective science instruction. 
Meanwhile, another possible factor which constrains the teachers' knowledge about students' alternative conceptions is the lack of teachers' understanding about the characteristics of an alternative conception itself. Morrison and Lederman (2003) found that teachers seemed not to be clear about what an alternative conception actually means. The teachers tended to regard an alternative conception as what students had learned in previous courses or which originated from students' confusion between science terms. It was also reported that preservice science teachers tend to view students' alternative conceptions as a mistake to be corrected or eliminated (Davis et al. 2006; Mellado 1997). Larkin (2012), in the study of pre-service teachers' view on students' ideas, suggested that the majority of teachers do not understand the value and the role of students' alternative conceptions. That is, teachers regarded students' alternative conceptions as an obstacle to understanding, not a tool to prime students' thinking, interest, and activity or an element to encourage a positive classroom environment. As Duit et al. (2008) reported, although some teachers seemed to be informed of the importance of students' conceptions, there were few teachers who have an explicit constructivist view of teaching and learning that might lead to the effective use of students' conceptions in their science classes. If teachers suppose that students' alternative conceptions are just evidence of their incorrect understanding of scientific concepts, it would be not likely for the teachers to probe students' alternative conception, to acknowledge them as a foundation upon which a new conception is built on, and then to try to help students reconstruct their cognitive structure.

Not only the students but also the teachers were found to have some alternative conceptions that are not compatible with scientific concepts. For example, about one third of teachers did not think that water vapor exists inside the bubble of boiling water. About $20 \%$ of teachers also think that the air from outside forms liquid drops. Previous studies have reported that some teachers hold inadequate conceptions, which are not scientifically accepted (Burgoon et al. 2010; Papageorgiou and Sakka 2000; Smith and Neale 1991). Furthermore, many of these conceptions are similar to those held by students (Mant and Summers 1995; Papageorgiou et al. 2010; Quílez-Pardo and Solaz-Portole's 1995). For the teachers possessing scientifically incorrect conceptions, we cannot expect them to help students construct new ideas. We should be, in fact, apprehensive that 
these teachers might serve as another substantial source of students' alternative conceptions (Gomez-Zwiep 2008).

Among teachers' characteristics, teaching experience, highest academic degree, and science teaching efficacy were found not to influence their awareness of students' alternative conceptions. It has been suggested that experienced teachers are likely to possess more PCK, including the knowledge about students' alternative conceptions than novice teachers (Akerson et al. 2000; Angell et al. 2005; Hogan et al. 2003). Meyer (2004) also reported that novice teachers think of students' prior knowledge as the information base upon which new information could be added, whereas experienced teachers regard it as a bridge to integrating new information to create better explanations. As a result, it has been assumed that experienced teachers would be more effective than novice teachers in adjusting the process of science instruction by focusing on students' difficulties (Gullberg et al. 2008; van Driel et al. 1998). However, the result of this study indicated that there was no significant difference between the experienced and the novice teachers in correctly predicting students' alternative conceptions. Some previous studies also pointed out that teaching experience does not ensure teachers knowledge about students' alternative conceptions (Caillods et al. 1997; Diakidoy and Iordanou 2003; GomezZwiep 2008; Halim and Meerah 2002). Unlike our initial expectations, more educated and higher self-efficacious teachers were not also found to be more effective in correctly predicting students' alternative conceptions. That is, the courses taken in graduate school and teachers' belief in their teaching ability do not guarantee a better understanding of students' learning difficulties just as teaching experience does not.

Hashweh (1996) showed that science teachers who hold a constructivist view for teaching and learning were more likely to detect students' alternative conceptions than those who hold a traditional view. In this study, however, it was found that teachers' prediction of students' alternative conceptions is significantly related not to the levels of their constructivist view but to the level of traditional view about teaching and learning. Käpylä et al. (2009) also reported a similar result, that more constructivist teachers were not better than their counterparts in understanding students' alternative conceptions. This result is interesting in consideration of the previous studies (Chan and Elliott 2004; Kang and Wallace 2005; Zohar 2004), which unanimously emphasized the influence of teachers' constructivist beliefs 
about teaching and learning on their actual teaching behaviors. This inconsistency might stem from the fact that the teachers did not completely become constructivist teachers who could implement a constructivist approach in their science classes though they themselves believed that they already know what constructivism means and what they should do as a constructivist teacher. As Prawat (1992) pointed out, a constructivist view about teaching and learning is unlikely to be obtained without a good deal of efforts on the part of teachers. Therefore, it might be possible that the teachers, who thought of themselves as holding a constructivist view, actually did not completely abandon a traditional view. That is, they might hold a dualistic view about teaching and learning (Bryan 2003; Haney and McArthur 2002). Furthermore, the result that the number of correctly predicted major alternative conceptions was negatively related to the level of their traditional view about teaching and learning might indicate that abandoning a traditional view should be a more important factor than knowing a constructivist view in predicting whether a teacher internalizes a constructivist view about teaching and learning, at least concerning the role and the importance of students' alternative conceptions in science instruction.

\section{Implications}

Although it has been already pointed out in 1980s that teachers are largely unaware of and are frequently not sensitive to students' beliefs and conceptions which they bring to science classes (Osborne et al. 1983), relatively little attention has been paid to the teachers' knowledge about students' alternative conceptions. As a result, recent studies, including this study, unanimously reported that teachers are still not sufficiently aware of students' alternative conceptions (Diakidoy and Iordanou 2003; Halim and Meerah 2002; Käpylä et al. 2009). Teachers who are informed about the types of alternative conceptions held by students are likely to be better at identifying them, at helping students call them to mind and make explicit, and at incorporating them into the processes of learning scientific concepts (Burgoon et al. 2010; Pine et al. 2001; Taber 2001). Therefore, not only should innovative instructional methods attract many researchers' and teachers' attention (as an essential component for constructivist 
teaching and learning) but also teachers' knowledge about students' potential alternative conceptions should command more concentrated efforts within the contexts of both pre-service and in-service education. Moreover, it was reported that, even though some teachers are aware of students' alternative conceptions, they do not consider them as a starting point of their science lessons (Davis and Smithey 2009; Halim and Meerah 2002; Smith 1999). Therefore, information concerning the types and the distribution of representative students' alternative conceptions as well as the knowledge about how to use students' alternative conceptions in the learning of scientific concepts should also be provided for teachers.

PCK exhibits a positive correlation to more effective instruction and students' achievement (Ball et al. 2005), and thus PCK has been used as a framework in designing elementary science teacher preparation programs (Davis and Smithey 2009; Nilsson 2008; van Driel and Berry 2010). Teachers' PCK, the knowledge about students' alternative conceptions in particular, is content-specific and has limited transfer to other situations. That is, how to diagnose and how to manage students' difficulties originating from their alternative conceptions is not necessarily the same among different science topics. Therefore, pre-service teachers need to be informed of students' common alternative conceptions on various science topics in order to adjust their future lessons. It was generally believed that, if teachers were given innovative methods and were shown how to use them, they would be able to effectively facilitate students' learning (Pringle 2006). However, teachers tend to teach the way they were taught. That is, merely rendering pre-service teachers to be informed of and to be exposed to students' alternative conceptions through a definition and examples is not enough to ensure that they would be adequately prepared to address students' alternative conceptions in their own classes (Gomez-Zwiep 2008; Halim and Meerah 2002). Special emphases should be made with respect to pre-service teachers' experiences in order to induce a meaningful change. As Loughran (2002) suggested, learning through experiences with real situations would be crucial for teachers to understand students and develop their own professional knowledge. Therefore, the courses comprising the curriculum of a teacher preparation program could provide experiences with an appropriate focus on real situations, wherein pre-service teachers could become confident in their abilities to diagnose, to confront, and to manage students' 
alternative conceptions. For example, it might be an effective method to provide pre-service teachers with the opportunity to teach a lesson several times during a science teaching methods course. Goldberg et al. (2006) demonstrated an example of teacher preparation programs which focus on increasing teachers' awareness and understanding of students' prior knowledge of various concepts in physics.

\section{Further Studies}

Since similarities between teachers' and students' conceptions of various science topics have been demonstrated (e.g., Burgoon et al. 2010; Kruger et al. 1990), the importance of teachers' understanding of science topics has been repeatedly emphasized. Even after three decades of research on conceptual change, however, it was found that elementary teachers still possess certain conceptions which are not consistent with scientific concepts and are rather similar to those of their students (Burgoon et al. 2010; Papageorgiou et al. 2010; Qu1'lez-Pardo and Solaz-Portole's 1995). Teachers with a rich knowledge base and a deep level of understanding about science concepts could be expected to be better able to help students develop the appropriate understanding of those new science concepts (Driver et al. 1994b). Akerson (2005) also suggested that elementary teachers who become more aware of students' alternative conceptions might become more knowledgeable about the content themselves. In their study on preservice science teachers' PCK, Halim and Meerah (2002) reported that teachers who had problems in understanding the scientific concepts were less likely to be aware of students' alternative conceptions. That is, teachers with relevant knowledge about students' alternative conceptions would seek to address their students' ideas and might be likely to exert more efforts to fully understand science concepts which they want to teach. On the contrary, Diakidoy and Iordanou (2003) reported that no significant predictive relationship was found between the teachers' level of concept understanding and their ability to predict students' level of knowledge. Considering these inconsistent results from previous studies, therefore, further research is needed to find out the relationship between teachers' subject content knowledge and their understanding of students' difficulties stemming from alternative conceptions. 


\section{Appendix}

\section{Question 1}

When water boils in a pot, one can observe big bubbles in the water. What does the bubble consist of?

\section{Question 2}

A balloon is tightly fitted at the top of a test tube containing a small amount of water. The test tube, the water, and the balloon weigh $65 \mathrm{~g}$ altogether. On heating the test tube, the water in the test tube disappears while the balloon is inflated. If one weigh the test tube with the inflated balloon, the weight will be ...

a. Less than $65 \mathrm{~g}$

b. More than $65 \mathrm{~g}$

c. Equal to $65 \mathrm{~g}$

\section{Question 3}

A glass is filled with ice cubes. The lid is closed tightly and the outer surface of the glass is dried with a towel. After $15 \mathrm{~min}$, the outer surface of the glass is wet. Where do the drops on the outer surface of the glass come from?

\section{Question 4}

A glass, the water in the glass, and a sugar cube weigh $200 \mathrm{~g}$ altogether. After dropping the sugar cube into the glass, the water is stirred until the sugar completely disappears. If one weigh the glass with the water containing the dissolved sugar, the weight will be ...

a. Less than $200 \mathrm{~g}$

b. More than $200 \mathrm{~g}$

c. Equal to $200 \mathrm{~g}$

\section{Question 5}

A spoon of salt is poured into a glass with water. The water is stirred until the salt completely dissolved. If one respectively tastes the upper part, the lower part, and the middle part of the solution 1 day later, which part will taste the saltiest?
a. The upper part
b. The lower part
c. The middle part
d. Any part of the solution will taste the same 


\section{References}

Adams, P. E., \& Krockover, G. H. (1997). Beginning science teacher cognition and its origin in the preservice secondary science teacher program. Journal of Research in Science Teaching, 34(6), 633-653.

Akerson, V. L. (2005). How do elementary teachers compensate for incomplete science content knowledge? Research in Science Education, 35(2/3), 245-268.

Akerson, V. L., Flick, L. B., \& Lederman, N. G. (2000). The influence of primary children's ideas in science on teaching practice. Journal of Research in Science Teaching, 37(4), 363-385.

American Association for the Advancement of Science (AAAS). (1993). Benchmarks for science literacy, Project 2061. New York: Oxford University Press.

Angell, C., Ryder, J., \& Scott, P. H. (2005). Becoming an expert teacher: Novice physics teachers' development of conceptual and pedagogical knowledge. Paper presented at the European Science Education Research Association Conference, Barcelona.

Appleton, K. (2003). How do beginning primary school teachers cope with science? Toward an understanding of science teaching practice. Research in Science Education, 33(1), 1-25.

Ball, D. L., Hill, H. H., \& Bass, H. (2005). Knowing mathematics for teaching. American Educator, 29(3), 14-46.

Bandura, A. (1997). Self efficacy: The exercise of control. New York: W. H. Freeman \& Company.

Bar, V., \& Travis, A. S. (1991). Children's views concerning phase changes. Journal of Research in Science Teaching, 28(4), 363-382.

Barker, V. (2002). Beyond misconceptions: Students' misconceptions about basic chemical ideas. London: Royal Society of Chemistry.

Barnett, M. (2002). Addressing children's alternative frameworks of the moon's phases and eclipses. International Journal of Science Education, 24(8), 859-879.

Barnett, J., \& Hudson, D. (2001). Pedagogical context knowledge: Toward a fuller understanding of what good science teachers know. Science Education, 85(4), 426-453.

Berg, T., \& Brouwer, W. (1991). Teacher awareness of student alternate conceptions about rotational motion and gravity. Journal of Research in Science Teaching, 28(1), 3-18.

Bleicher, R. E. (2004). Revisiting the STEBI-B: Measuring self-efficacy in preservice elementary teachers. School Science and Mathematics, 104(8), 383-391.

Borko, H., \& Putnam, R. T. (1996). Learning to teach. In R. C. Calfee \& D. C. Berliner (Eds.), Handbook of Educational Psychology. New York: Macmillan.

Brown, D. F., \& Rose, T. J. (1995). Self-reported classroom impact of teachers' theories about learning and obstacles to implementation. Action in Teacher Education, 17(1), 20-29. 
Bryan, L. A. (2003). Nestedness of beliefs: Examining a prospective elementary teacher's belief system about science teaching and learning. Journal of Research in Science Teaching, 40(9), 835-868.

Burgoon, J. N., Heddle, M. L., \& Duran, E. (2010). Re-examining the similarities between teacher and student conceptions about physical science. Journal of Science Teacher Education, 21(7), 859-872.

Caillods, F., Gottelmann-Duret, G., \& Lewin, K. (1997). Science Educational Development. Paris: Ergamon.

Chan, K.-W., \& Elliott, R. G. (2004). Relational analysis of personal epistemology and conceptions about teaching and learning. Teaching and Teacher Education, 2O(8), 817-831.

Chaney, B. (1995). Student outcomes and the professional preparation of eighthgrade teachers in science and mathematics: NSF/ NELS:88 Teacher transcript analysis. Rockville, MD: Westat.

Chi, M. T. H. (2005). Commonsense conceptions of emergent processes: Why some misconceptions are robust. The Journal of Learning Sciences, 14(2), 161-199.

Crespo, M. A. G., \& Pozo, J. I. (2004). Relationships between everyday knowledge and scientific knowledge: Understanding how matter changes. International Journal of Science Education, 26(11), 1325-1343.

Darling-Hammond, L. (2000). Teacher quality and student achievement: A review of state policy evidence. Education Policy Analysis Archives, 8(1), 1-50.

Davis, E. A., Petish, D., \& Smithey, J. (2006). Challenges new science teachers face. Review of Educational Research, 76(4), 607-651.

Davis, E. A., \& Smithey, J. (2009). Beginning teachers moving toward effective elementary science teaching. Science Education, 93(4), 745-770.

Diakidoy, I. N., \& Iordanou, K. (2003). Preservice teachers' and teachers' conceptions of energy and their ability to predict pupils' level of understanding. European Journal of Psychology of Education, 18(4), 357-368.

Driver, R., Asoko, H., Leach, L., Mortimer, E., \& Scott, P. (1994a). Constructing scientific knowledge in the classroom. Educational Researcher, 23(7), 5-12.

Driver, R., Guesne, E., \& Tiberghien, A. (1985). Children's idea in science. Milton Keynes: Open University Press.

Driver, R., Squires, A., Rushworth, P., \& Wood-Robinson, V. (1994b). Making sense of secondary science research into children's ideas. New York: Routledge.

Duit, R. T., Treagust, D. F., \& Widodo, A. (2008). Teaching science for conceptual change: Theory and practice. In S. Vosniadou (Ed.), International handbook of research on conceptual change (pp. 629-646). New York: Routledge.

Enochs, L. G., Scharmann, L. C., \& Riggs, I. M. (1995). The relationship of pupil control to preservice elementary science teacher self-efficacy and outcome expectancy. Science Education, 70(1), 63-75.

Enochs, L. G., Smith, P. L., \& Huinker, D. (2000). Establishing factorial validity of the mathematics teaching efficacy beliefs instrument. School Science and Mathematics, 100(4), 194-203. 
Eryilmaz, A. (2002). Effects of conceptual assignments and conceptual change discussions on students' misconceptions and achievement regarding force and motion. Journal of Research in Science Teaching, 39(10), 1001-1015.

Fishman, B. J., Marx, R. W., Best, S., \& Tal, R. T. (2003). Linking teacher and student learning to improve professional development in systemic reform. Teaching and Teacher Education, 19(6), 643-658.

Garnett, P. J., Garnett, P. J., \& Hackling, M. W. (1995). Students' alternative conceptions in chemistry: A review of research and implications for teaching and learning. Studies in Science Education, 25(1), 69-95.

Germann, P. J., \& Barrow, L. H. (1995). In-service needs of teachers of biology: A comparison between veteran and nonveteran teachers. American Biology Teacher, 57(5), 272-277.

Gess-Newsome, J., \& Lederman, N. G. (Eds.). (1999). Examining pedagogical content knowledge. Dordrecht: Kluwer.

Gimmestad, M. J., \& Hall, G. E. (1995). Structure of teacher education programs. In L. Anderson (Ed.), International encyclopedia of teaching and teacher education (2nd ed.). Oxford: Elsevier Science.

Goldberg, F., Robinson, S., \& Otero, V. (2006). Physics for elementary teachers. Armonk: It's about time.

Gomez-Zwiep, S. (2008). Elementary teachers' understanding of students' science misconceptions: Implications for practice and teacher education. Journal of Science Teacher Education, 19(5), 437-454.

Grossman, P. (1990). The making of a teacher: Teacher knowledge and teacher education. New York: Teachers College Press.

Gullberg, A., Kellner, E., Attorps, I., Thoren, I., \& Tarneberg, R. (2008). Prospective teachers' initial conceptions about pupils' understanding of science and mathematics. European Journal of Teacher Education, 31(3), 257-278.

Guskey, T. R. (1988). Teacher efficacy, self-concept, and attitudes toward the implementation of instructional innovation. Teaching and Teacher Education, 4(1), 63-69.

Halim, L., \& Meerah, S. M. (2002). Science trainee teachers' pedagogical content knowledge and its influence on physics teaching. Research in Science and Technological Education, 20(2), 215-225.

Haney, J. J., \& McArthur, J. (2002). Four case studies of prospective science teachers' beliefs concerning constructivist teaching practices. Science Education, 86(6), 783-802.

Hashweh, M. Z. (1996). Effects of science teachers' epistemological beliefs in teaching. Journal of Research in Science Teaching, 33(1), 47-263.

Hashweh, M. Z. (2005). Teacher pedagogical constructions: A reconfiguration of pedagogical content knowledge. Teachers and Teaching: Theory and Practice, 11(3), 273-292.

Hatzinikita, V., \& Koulaidis, V. (1997). Pupils' ideas on conservation during changes in the state of water. Research in Science and Technological Education, 15(1), 53-70. 
Hogan, T., Rabinowitz, M., \& Craven, J. A. (2003). Representation in teaching: Inferences from research of expert and novice teachers. Educational Psychologist, 38(4), 235-247.

Holding, B. (1987). Investigation of schoolchildren's understanding of the process of dissolving with special reference to the conservation of matter and the development of atomistic ideas. Unpublished Doctoral Dissertation, University of Leeds.

Johnson, P. (1997). Understanding chemical change: What does it take? Paper presented at the annual conference of the Association for Science Education, Birmingham.

Johnson, P. (1998). Children's understanding of changes of state involving the gas state, part 1: Boiling water and the particle theory. International Journal of Science Education, 20(5), 567-583.

Kang, S., Scharmann, L. C., \& Noh, T. (2004). Reexamining the role of cognitive conflict in science concept learning. Research in Science Education, 34(1), 71-96.

Kang, N.-H., \& Wallace, C. S. (2005). Secondary science teachers' use of laboratory activities: Linking epistemological beliefs, goals, and practices. Science Education, 89(1), 141-165.

Käpylä, M., Heikkinen, J.-P., \& Asunta, T. (2009). Influence of content knowledge on pedagogical content knowledge: The case of teaching photosynthesis and plant growth. International Journal of Science Education, 31(10), 1395-1415.

Kim, Y. G., \& Lee, K. J. (1998). The conception of elementary school student in regards to solution. Journal of the Science Education, 23, 269-283 (written in Korean).

Kruger, C. J., Summers, M. K., \& Palacio, D. J. (1990). An investigation of some English primary school teachers' understanding of the concepts force and gravity. British Educational Research Journal, 16(4), 383-397.

Larkin, D. (2012). Misconceptions about "misconceptions": Preservice secondary science teachers" views on the value and role of student ideas. Science Education, 96(5), 927-959.

Lederman, N. G., \& Niess, M. L. (2001). An attempt to anchor our moving targets. School Science and Mathematics, 101(2), 50-57.

Lim, C.-H. (2003). Science teaching practice and science teaching efficacy beliefs by development of elementary school teachers' pedagogical content knowledge. Journal of Korean Earth Science Society, 24(4), 258-272 (written in Korean).

Linn, M. C., \& Muillenburg, L. (1996). Creating lifelong science learners: What models form a firm foundation? Educational Researcher, 25(5), 18-24.

Linnenbrink, E. A., \& Pintrich, P. R. (2003). Achievement goals and intentional conceptual change. In G. M. Sinatra \& P. R. Pintrich (Eds.), Intentional conceptual change (pp. 347-374). Mahwah: Erlbaum.

Loughran, J. (2002). Effective reflective practice: In search of meaning in learning about teaching. Journal of Teacher Education, 53(1), 33-43. 
Loughran, J., Mulhall, P., \& Berry, A. (2004). In search of pedagogical content knowledge in science: Developing ways of articulating and documenting professional practice. Journal of Research in Science Teaching, 41(4), 370-391.

Lumpe, A. T., Haney, J. J., \& Czerniak, C. M. (2000). Assessing teachers' beliefs about their science teaching context. Journal of Research in Science Teaching, 37(3), 275-292.

Magnusson, S., Krajcik, J., \& Borko, H. (1999). Nature, sources, and development of pedagogical content knowledge for science. In J. Gess-Newsome \& N. G. Lederman (Eds.), Examining pedagogical content knowledge. Boston: Kluwer Academic Publisher.

Mant, J., \& Summers, M. (1995). Some primary school teachers' understanding of the earth's place in the universe. Research Papers in Education, 8(1), 101-129.

Marshall, J. C., Horton, R., Igo, B. L., \& Switzer, D. M. (2009). K-12 science and mathematics teachers' beliefs about and use of inquiry in the classroom. International Journal of Science and Mathematics Education, 7(3), 575-596.

Mellado, V. (1997). Preservice teachers' classroom practice and their conceptions of the nature of science. Science \& Education, 6(4), 331-354.

Mellado, V., Blanco, L. J., \& Ruiz, C. (1998). A framework for learning to teach science in initial primary teacher education. Journal of Science Teacher Education, 9(3), 195-219.

MEST. (2009). Education in Korea. Seoul: Ministry of Education, Science and Technology.

Meyer, H. (2004). Novice and expert teachers' conceptions of learners' prior knowledge. Science Education, 88(6), 970-983.

Monk, D. H. (1994). Subject area preparation of secondary mathematics and science teachers and student achievement. Economics of Education Review, 13(2), 125-145.

Morrison, J. A., \& Lederman, N. G. (2003). Science teachers' diagnosis and understanding of students' preconceptions. Science Education, 87(6), 849-867.

Moyer-Packenham, P. S., Bolyard, J. J., Kitsantas, A., \& Oh, H. (2008). The assessment of mathematics and science teacher quality. Peabody Journal of Education, 83(4), 562-591.

National Center on Education and the Economy (NCEE). (2006). Tough choices for tough times: The report of the new commission on the skills of the American workforce. Washington, DC: National Center on Education and the Economy.

National Research Council (NRC). (1996). National science education standards. Washington, DC: National Academy Press.

Nilsson, P. (2008). Teaching for understanding: The complex nature of pedagogical content knowledge in pre-service education. International Journal of Science Education, 30(10), 1281-1299.

Noh, T., Cha, J., Kang, S., \& Scharmann, C. (2004). Perceived professional needs of Korean science teachers majoring in chemical education and their preferences for online and on-site training. International Journal of Science Education, 26(10), 1269-1289. 
Noh, K. J., \& Kim, H. N. (1996). Elementary school children's conceptions about dissolution according to scientific and everyday context. Elementary Science Education, 15(2), 233-250 (written in Korean).

OECD. (2005). Teachers matter: Attracting, developing and retaining effective teachers. Paris: Organization for Economic Co-operation and Development.

Osborne, R. J., Bell, B. F., \& Gilbert, J. K. (1983). Science teaching and children's views of the world. European Journal of Science Education, 5(1), 1-14.

Osborne, R. J., \& Cosgrove, M. M. (1983). Children's conceptions of the changes of state of water. Journal of Research in Science Teaching, 2o(9), 825-838.

Otero, V. K., \& Nathan, M. J. (2008). Preservice elementary teachers' views of their students' prior knowledge of science. Journal of Research in Science Teaching, 45(4), 497-523.

Papageorgiou, G., \& Sakka, D. (2000). Primary school teachers' views on fundamental chemical concepts. Chemistry Education Research and Practice in Europe, 1(2), 237-247.

Papageorgiou, G., Stamovlasis, D., \& Johnson, P. M. (2010). Primary teachers' particle ideas and explanations of physical phenomena: Effect of an in-service training course. International Journal of Science Education, 32(5), 629-652.

Pine, K., Messer, D., \& John, K. (2001). Children's misconceptions in primary science: A survey of teachers' views. Research in Science and Technological Education, 19(1), 79-96.

Prawat, R. S. (1992). Teachers' beliefs about teaching and learning: A constructivist perspective. American Journal of Education, 100(3), 354-395.

Pringle, R. M. (2006). Preservice teachers' exploration of children's alternative conceptions: Cornerstone for planning to teach science. Journal of Science Teacher Education, 17(3), 291-307.

Quílez-Pardo, J., \& Solaz-Portole's, J. J. (1995). Students' and teachers' misapplication of Le Châtelier's principle: Implications for the teaching of chemical equilibrium. Journal of Research in Science Teaching, 32(9), 939-957.

Rahayu, S., \& Tytler, R. (1999). Progression in primary school children's conceptions of burning: Toward an understanding of the concept of substance. Research in Science Education, 29(3), 295-312.

Riggs, I. M., \& Enochs, L. G. (1990). Toward the development of an elementary teacher's science teaching efficacy belief instrument. Science Education, 74(6), 625-637.

Sanders, M. (1993). Erroneous ideas about respiration: The teacher factor. Journal of Research in Science Teaching, 30(8), 919-934.

Smith, D. C. (1999). Changing our teaching: The role of pedagogical content knowledge in elementary science. In J. Gess-Newsome \& N. G. Lederman (Eds.), Examining pedagogical content knowledge (pp. 163-197). Netherlands: Kluwer Academic.

Smith, D. C., \& Neale, D. C. (1991). The construction of subject matter knowledge in primary science teaching. In J. Brophy (Ed.) Advances in research on teaching (Vol. 2, pp. 187-243). Greenwich, CT: JAI Press. 
Southerland, S., Abrams, E., Cummins, C., \& Anzelmo, J. (2001). Understanding students' explanations of biological phenomena: Conceptual frameworks or p-prims? Science Education, 85(4), 328-348.

Staver, J. R., \& Pascarella, E. T. (1984). The effects of method and format on the responses of subjects to a Piagetian reasoning problem. Journal of Research in Science Teaching, 21(3), 305-314.

Stavy, R. (1990). Children's conception of changes in the state of matter: From liquid (or solid) to gas. Journal of Research in Science Teaching, 27(3), 247-266.

Taber, K. S. (2001). The mismatch between assumed prior knowledge and the learner's conceptions: A typology of learning impediments. Educational Studies, 27(2), 159-171.

Tschannen-Moran, M., \& Hoy, A. W. (2001). Teacher efficacy: Capturing an elusive construct. Teaching and Teacher Education, 17(7), 783-805.

van Driel, J. H., \& Berry, A. (2010). Pedagogical content knowledge. In P. Peterson, E. Baker, \& B. McGaw (Eds.), International Encyclopedia of Education (3rd ed., pp. 656-661). UK: Elsevier.

van Driel, J. H., Verloop, N., \& de Vos, W. (1998). Developing science teachers' pedagogical content knowledge. Journal of Research in Science Teaching, 35(6), 673-695.

Vosniadou, S. (2003). Exploring the relationships between conceptual change and intentional learning. In G. M. Sinatra \& P. R. Pintrich (Eds.), Intentional conceptual change (pp. 377-406). Mahwah: Erlbaum.

Wandersee, J. H., Mintzes, J. J., \& Novak, J. D. (1994). Research on alternative conceptions in science. In D. L. Gabel (Ed.), Handbook of research on science teaching and learning (pp. 177-210). New York: MacMillan.

Watts, D., \& Zylbersztajn, A. (1981). A survey of some children's ideas about force. Physics Education, 16(6), 360-365.

Woolfolk Hoy, A., \& Burke-Spero, R. (2005). Changes in teacher efficacy during the early years of teaching: A comparison of four measures. Teaching and Teacher Education, 21(4), 343-356.

Zeidler, D. L. (2002). Dancing with maggots and saints: Visions for subject matter knowledge, pedagogical knowledge and pedagogical content knowledge in science teacher education reform. Journal of Science Teacher Education, 13(1), 27-42.

Zohar, A. (2004). Elements of teachers' pedagogical knowledge regarding instruction of higher-order thinking. Journal of Science Teacher Education, 15(4), 293-312. 